\title{
Spesimen Awetan dalam Blok Resin untuk Media Pembelajaran Biologi
}

\author{
Oleh: Budiwati \\ Staf pengajar FMIPA UNY
}

\section{Pendahuluan}

Biologi merupakan cabang Ilmu Pengetahuan Alam yang mempelajari struktur fungsi makhluk hidup dan interaksinya dengan lingkungan. Pembelajaran biologi idealnya dilakukan melalui tahap-tahap proses sains baik melalui eksperimen maupun observasi. Dengan melalui proses sains diharapkan peserta didik mampu membangun konsepnya sendiri. Sesuai dengan tuntutan kurikulum, proses pembelajaran di kelas seharusnya bisa menempatkan siswa sebagai subjek belajar, sementara tugas guru adalah memperkaya pengalaman belajar anak, membimbing dan menyediakan fasilitas.

Fakta di lapangan menunjukkan bahwa sebagian besar guru masih membelajarkan biologi secara verbal tanpa media atau alat peraga yang memadai. Model pembelajaran semacam ini akan menjadi penghambat perkembangan daya nalar, minat dan motivasi anak untuk belajar biologi. Kebanyakan guru biologi melaksanakan pembelajaran tanpa alat peraga dengan alasan tidak mempunyai banyak waktu untuk menyediakan atau di sekolah tidak mempunyai alat/bahan yang memadai. Sementara itu, ada beberapa guru memberikan alasan lain yaitu kurangnya pengetahuan dan pengalaman dalam penyediaan media atau alat peraga. Dengan kemauan dan kreativitas, sebenarnya guru dapat memanfaatkan objek-objek alam sekitar sebagai media atau alat peraga dalam pembelajaran. Penggunaan spesimen objek biologi tentu saja akan menambah ketertarikan siswa untuk belajar biologi, mengembangkan ketrampilan anak dalam hal pengamatan, mendeskripsi gejala struktural, mengukur, mengklasifikasi, menemukan masalah, dan menginterpretasi data.

\section{Spesimen Awetan}

Spesimen objek biologi sebagai media pembelajaran dapat digunakan dalam keadaan segar ataupun awetan, utuh ataupun sebagian, sesuai dengan kondisi dan tujuannya. Banyak objek biologi yang dapat ditemukan langsung di sekitar sekolah atau sekitar tempat tinggal siswa/guru. Guru dapat menggunakan objek itu dalam pembelajarannya, untuk dibawa ke kelas atau membawa siswa keluar kelas untuk mengamati secara langsung. Untuk objek-objek yang mudah diperoleh setiap saat dan jumlahnya berlimpah 
bisa disajikan dalam keadaan segar. Sedangkan untuk objek-objek yang tidak setiap saat bisa ditemukan dan jumlahnya terbatas, penggunaan media berupa spesimen atau preparat awetan menjadi sangat diperlukan. Spesimen awetan dapat disimpan dalam waktu yang lama dan dapat digunakan berkali-kali, sehingga akan mengurangi kerja guru dan meningkatkan efisiensi. Keuntungan lain penggunaan media pembelajaran biologi berupa spesimen atau preparat awetan adalah sebagai berikut.

1. Efektif mengenalkan gejala struktural objek

2. Mudah dilakukan setiap saat untuk pembelajaran biologi di kelas.

3. Tidak merusak sumber daya alam

4. Mudah dibawa atau dipindahkan

5. Mempermudah pengenalan objek, terutama untuk objek yang sulit ditemukan, jumlah terbatas, atau tidak setiap saat tersedia.

6. Membangkitkan dan meningkatkan minat dan motivasi belajar siswa

Pada prinsipnya, ada dua cara pengawetan objek biologi, yaitu pengawetan basah dan pengawetan kering. Pengawetan basah dilakukan dengan mengawetkan objek biologi dalam suatu cairan pengawet. Sedangkan pengawetan kering dilakukan dengan mengeringkan objek biologi hingga kadar air yang sangat rendah, sehingga organisme perusak/ penghancur tidak bekerja. Pengawetan basah biasanya dilakukan bagi hewan/ tumbuhan yang ukurannya cukup besar, dengan cara direndam dalam larutan pengawet. Pengawetan kering objek biologi yang cukup besar dalam bentuk utuh biasanya dilakukan dengan pengeringan di bawah sinar matahari atau oven. Objek biologi yang berukuran kecil misalnya spora, serbuk sari, jamur, plankton dan irisan/sayatan jaringan atau organ diawetkan dalam bentuk sedian mikroskopis (slide).

Spesimen tumbuhan maupun hewan dapat juga diawetkan dalam blok resin (sering dikenal dengan istilah bioplastik). Spesimen yang sesuai untuk diawetkan dalam blok resin adalah yang tidak terlampau kecil ukurannya dan tidak rusak strukturnya dalam kondisi kering. Bahan utama yang digunakan untuk pengawetan adalah cairan resin yang biasa digunakan dalam pembuatan fiberglass, pin, gantungan kunci, piala dan berbagai cindera mata yang lain.

Resin merupakan senyawa organik hasil metabolisme sekunder, tersusun atas karbon. Senyawa ini akan mengalami polimerisasi dalam kondisi yang tepat. Reaksi polimerisasi bersifat eksoterm sehingga akan menimbulkan panas. Bila dibiarkan di udara terbuka, secara alami proses polimerisasi berlangsung secara lambat. 


\section{Alat dan Bahan untuk Pengawetan Spesimen dalam Blok Resin}

1. Spesimen yang sudah dimatikan/dikeringkan.

2. Cairan resin

3. Untuk mempercepat polimerisasi resin digunakan katalis. Jumlah cairan katalis yang ditambahkan akan memengaruhi terhadap cepat atau lambatnya proses polimerisasi.

4. Peralatan dan bahan lain yang digunakan adalah gurinda atau kikir, amplas duco berbagai ukuran, gelas bekas air mineral, pengaduk, pinset, cetakan, label terbuat dari plastik transparan.

5. Untuk proses finishing biasanya digunakan compound, sanpoly atau kit dan kain halus untuk menggosok permukaan blok.

\section{Proses Pembuatan}

1. Penyiapan spesimen

Perlakuan awal pada spesimen perlu diperhatikan dengan benar. Salah penanganan dapat mengakibatkan hasil yang tidak memuaskan misalnya perubahan warna, bentuk, dan ukuran. Spesimen yang akan diblok dalam resin harus dalam keadaan kering. Pengeringan spesimen dapat dilakukan dengan cara dehidrasi di udara terbuka, menggunakan alkohol, kloroform, eter, atau dioven. Untuk spesimen tumbuhan dapat dikeringkan dengan cara pengepresan menggunakan buku tebal selama beberapa hari atau dikeringkan dengan menggunakan setrika. Pengeringan dengan menggunakan setrika harus dijaga benar agar suhu tidak terlalu panas. Jika terlalu panas, spesimen akan hangus.

2. Pembuatan Blok Resin

a. Siapkan cetakan, yakinkan bagian sudut dan tepi tidak bocor

b. Tuangkan resin secukupnya ke dalam gelas bekas air mineral, tambahkan katalis sambil diaduk perlahan. Menurut Setyadi (2004) perbandingan resin dan katalis kurang lebih $20: 1$. Namun sebenarnya tidak ada rumus yang baku untuk proses ini. Semuanya dilakukan dengan proses eksperimen. Dari hasil eksperimen akan dihasilkan perbandingan resin dan katalis untuk reaksi cepat, reaksi sedang, dan reaksi lambat. Jika terlalu banyak katalis akan menyebabkan spesimen mengalami pemanasan dan blok menjadi retak atau pecah. Jumlah katalis yang terlalu sedikit juga menyebabkan pembentukan blok menjadi lambat atau tidak kering dalam waktu yang dikehendaki. Dalam 
kondisi normal tanpa katalis resin akan memadat sekitar 24-48 jam. Suhu ruangan juga berpengaruh pada lamanya pemadatan resin.

c. Untuk membuat lapisan dasar, tuangkan campuran resin pada cetakan dengan ketebalan sekitar $0,5 \mathrm{~cm}$.

d. Apabila lapisan dasar sudah cukup kering, tempatkan spesimen yang sudah dipersiapkan dengan hati-hati. Bila diperlukan label, tempatkan secara bersamaan.

e. Buat campuran resin dan katalis untuk lapisan pengikat sedikit saja dan tuangkan dengan hati-hati pada spesimen yang telah diletakkan pada lapisan dasar.

f. Jika lapisan pengikat sudah membentuk gel (cek dengan ujung tusuk gigi). Tuangkan campuran resin dan katalis sebagai lapisan penutup. Gambar 1 menunjukkan penuangan campuran resin dan katalis untuk lapisan penutup.

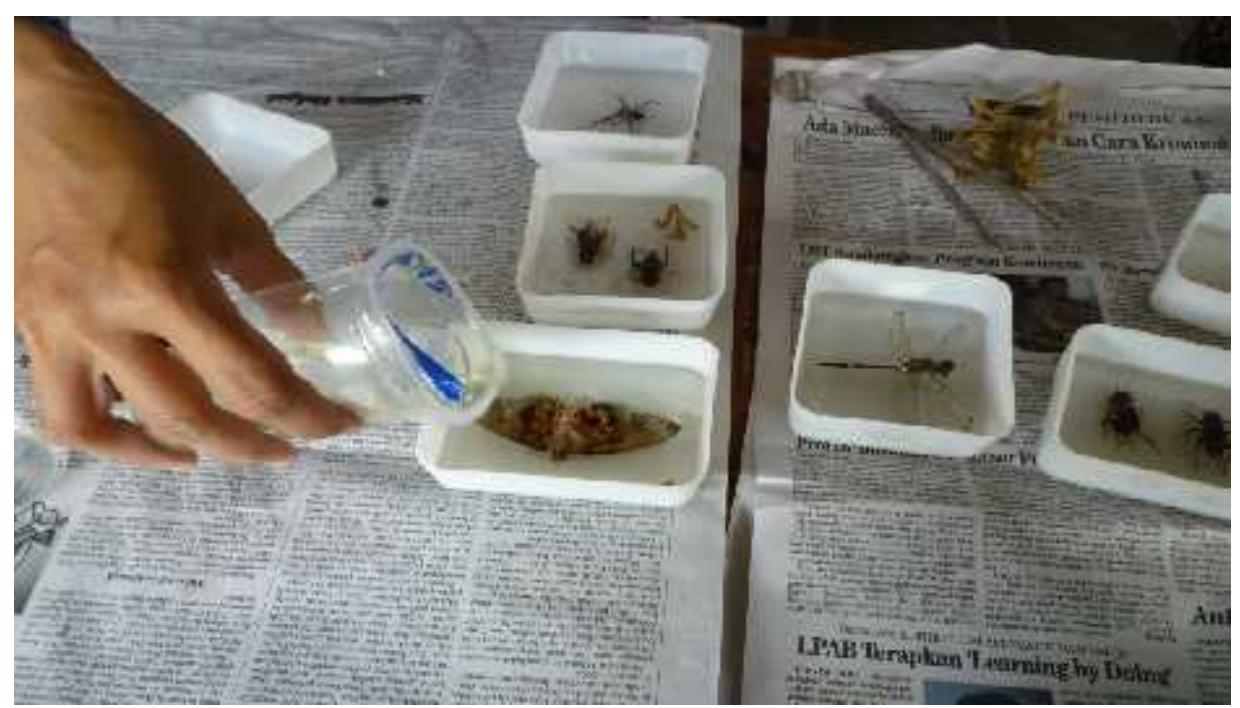

Gambar 1. Penuangan campuran resin dan katalis sebagai lapisan penutup

\section{Pembentukan, Penghalusan, dan Finishing}

Pembentukan dapat menggunakan gerinda, kikir atau amplas kasar. Pembentukan bertujuan untuk meratakan permukaan yang kasar dan membentuk blok yang tepat. Setelah proses pembentukan, dilanjutkan dengan proses penghalusan menggunakan amplas bertingkat dari yang kasar hingga yang halus. Proses terakhir adalah finishing, yang bertujuan untuk menghaluskan dan membuat transparan permukaan blok resin. Untuk proses finishing biasanya digunakan compound, sanpoly atau kit dan digosok dengan kain yang halus. Hasil finisfing blok resin ditunjukkan pada gambar 2, 3 dan 4. 


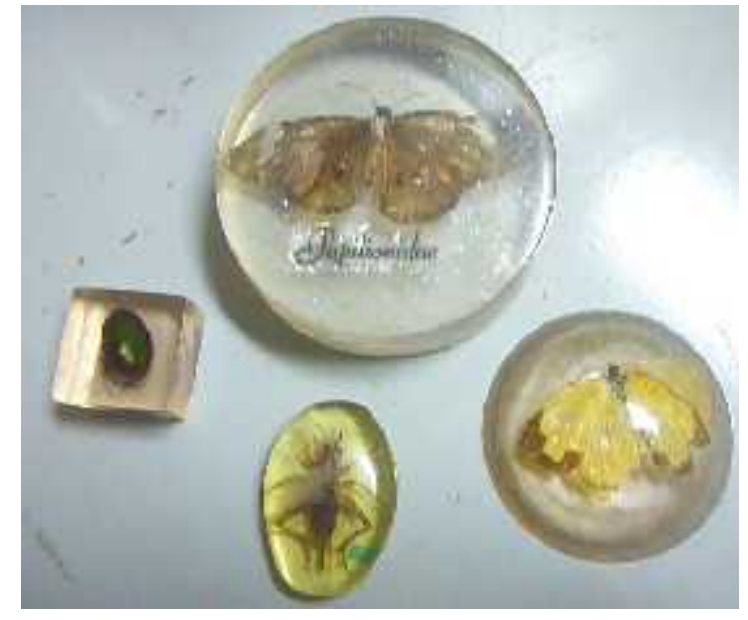

Gambar 2. Kupu-kupu dan serangga lain dapat diawetkan dalam blok resin

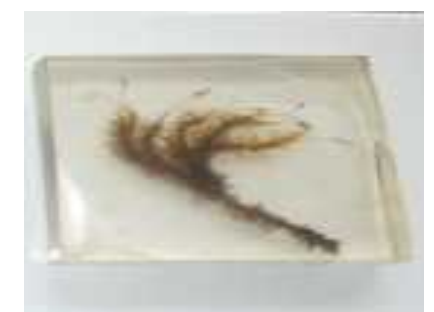

Gambar 3. Tumbuhan lumut dalam blok resin

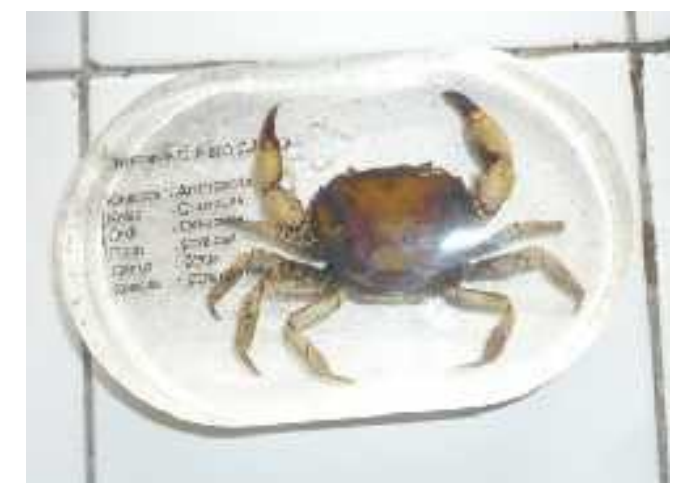

Gambar 4. Hewan kepiting dalam blok resin

\section{Kelebihan dan Kekurangan Spesimen Awetan dalam Blok Resin}

Pada bagian sebelumnya telah disampaikan beberapa keuntungan penggunaan spesimen awetan secara umum. Berikut ini merupakan kelebihan spesimen awetan dalam blok resin.

1. Spesimen yang diawetkan bisa dilihat dari semua sisi sehingga gejala struktural objek dapat teramati.

2. Selain sebagai media pembelajaran, dapat juga digunakan sebagai hiasan (ornamen) 
3. Keindahan objek dapat terjaga dan dapat dilihat secara utuh sehingga dapat meningkatkan minat dan motivasi siswa dalam mempelajari objek tersebut.

4. Lebih kuat dan tahan lama dibandingkan spesimen awetan lain seperti insektarium dan herbarium.

5. Siswa dapat memanfaatkan media untuk belajar sambil bermain. Sebagai contoh untuk mempelajari urutan dan ciri-ciri tiap fase dalam siklus hidup kupu-kupu, setiap tahap/fase diawetkan dalam blok-blok resin yang terpisah. Ketika akan digunakan blok-blok spesimen diletakkan secara acak kemudian siswa diminta untuk mengamati ciri-ciri tiap fase dan mengurutkannya dengan benar.

6. Praktis dalam penyimpanan.

Meskipun memiliki banyak kelebihan, namun penggunaan spesimen awetan dalam blok resin juga mempunyai kekurangan. Salah satu di antaranya adalah spesimen tidak dapat disentuh/diraba sehingga gejala objek yang bisa diobservasi hanyalah gejala struktural yang mengandalkan indera penglihatan saja.

\section{Penutup}

Banyak macam media pembelajaran biologi yang dapat digunakan oleh guru. Masingmasing jenis media mempunyai kelebihan dan kekurangan. Salah satu alternatif media pembelajaran biologi yang dapat digunakan oleh guru adalah spesimen awetan dalam blok resin. Apapun media yang menjadi pilihan guru, diharapkan sesuai dengan tujuan pembelajaran, dapat meningkatkan minat dan motivasi belajar, serta dapat mengoptimalkan daya nalar siswa.

\section{Daftar Pustaka:}

Bambang Ruwanto. “ Pembelajaran (Sains) Berbasis Lingkungan.“ Kedaulatan Rakyat, 6 September 2012, h.12

Seregeg, G. Wayan. 2004. Pengembangan Paradigma Pembelajaran untuk Meningkatkan Profesionalisme Guru Biologi. Proceeding National Science Education Seminar on The Problem of Mathematics and Science Education and Alternatives to Solve The Problems. February 23, 2000. Malang: FMIPA, State University of Malang (UM).

Setyadi, B. 2004. Bioplastik. Makalah Pelatihan. Universitas Pendidikan Indonesia Bandung

Trianto. 2010. Model Pembelajaran Terpadu. Konsep, Strategi, dan Implementasinya dalam Kurikulum Tingkat Satuan Pendidikan (KTSP). Jakarta: Penerbit Bumi Aksara 